А. А. Слепых, аспирант

И. И. Коршиков, д.б.н., проф.

Криворожский ботанический сад НАН Украины

ул. Маршака, 50, Кривой Рог, 50089, Украина, e-mail: aleksandr_slepykh@mail.ru

\title{
ИЗМЕНЧИВОСТЬ ДУБА ЧЕРЕШЧАТОГО (QUERCUS ROBUR L.) ПО ФЕНОТИПИЧЕСКИМ ПРИЗНАКАМ ЛИСТЬЕВ В СТЕПНОЙ ЗОНЕ УКРАИНЫ
}

Исследована изменчивость (эндогенная, индивидуальная и экологогеографическая) 12-ти местопроизрастаний дуба черешчатого ( $Q$. robur L.) в условиях сухостепной зоны на Донбассе по морфологическим признакам листьев. Выявлена высокая вариабельность 8 эмпирических и 3-х относительных показателей. Уровень индивидуальной изменчивости дубрав Украинской степи составил 5,3 \%. На основе показателей морфометрии листьев был проведен кластерный анализ, который выявил две неравноценных группы, в одну из которых вошло 10 исследуемых районов произрастания.

Ключевые слова: Quercus robur L., морфологические признаки, фенотипическая изменчивость, популяция, кластерный анализ.

Дуб черешчатый (Q. robur L.) является аборигенным видом и одной из главных лесообразующих пород Украины, обладает высоким адаптационным потенциалом, чему способствует дальний перенос пыльцы до 50-80 км [19, 24]. Дуб формирует небольшие устойчивые популяции в условиях сухой Степи. В степной зоне Украины, которая занимает 40 \% территории страны, здесь Q. robur представлен малочисленными изолированными популяциями, которые часто подвергаются избыточному антропогенному влиянию. Это незаконные вырубки, локальные пожары, выпас скота и т. д. [16]. Вне заповедных территорий в степной зоне популяции дуба черешчатого находятся под угрозой исчезновения. В связи с глобальными климатическими изменениями и возрастающей антропогенной нагрузкой, отмечается деградация и массовое усыхание дубрав практически во всех частях ареала вида [4].

Опыт лесоразведения показывает, что дуб имеет незначительные перспективы относительно естественного возобновления семенным путем в искусственных насаждениях и байрачных лесах в степных условиях $[4,5,16]$.

Ареал Q. robur занимает почти всю Западную и значительную часть Восточной Европы (кроме северных регионов), простираясь в восточном направлении до Урала $[6,9]$. Естественный лесовосстановительный процесс у древесных растений в значительной степени обусловлен средой обитания в том или ином географическом районе и конкретными условиями произраста- 
ния в пределах района, что относится к $Q$. robur в полной мере. Встречаемость дубрав ухудшается в направлении от западных районов ареала к восточным $[14,16]$. Изучение популяций дуба особо актуально на крайних приграничных территориях ареала.

Стоит отметить, что исследования популяционной структуры $Q$. robur в сухостепной зоне Украины, в частности, в Донецкой области, раннее практически не проводились [29], что вызывает особый интерес.

Существующие дубовые насаждения, группы и отдельные экземпляры, вступившие в репродуктивную фазу, являются ценными объектами для семеноводства дуба. Произрастая в сложных микроклиматических условиях, они прошли процесс естественного отбора на засухоустойчивость, толерантность к почвенному плодородию, морозостойкость и могут обоснованно считаться генетическим резерватом популяции $Q$. robur $[21,28]$.

Изучение закономерностей и уровней фенотипической изменчивости Q. robur даст возможность оценить устойчивость и эволюционную приверженность некоторых популяций и вида дуба черешчатого в целом. Это, возможно, будет способствовать разработке мер по сохранению генофонда Q. robur [11], фенотипическое разнообразие которого в сухостепной зоне Украины в полной мере не исследовано.

Внутривидовая изменчивость дуба черешчатого, которая, как правило, встречается внутрипопуляционными группами, географическими и экологическими популяциями является базисом для поиска, сохранения и рационального использования его генетического потенциала. Интерес особого значения представляют маргинальные [8] (приграничные) популяции $Q$ robur на юго-восточном пределе естественного ареала распространения в Донецкой области. В краевых частях ареала дуб испытывает не только антропогенный пресс, но и негативное влияние абиотических факторов, так как условия обитания здесь резко отличаются от условий центральной части его ареала и в большинстве случаев являются субоптимальными [9, 13]. На дуб большое влияние оказывает и нарушение водного режима. Исследование центральных и маргинальных местообитаний дуба дает информацию о формовом разнообразии данного вида, о существовании особых, менее требовательных к теплу форм и позволяет провести их отбор для введения в культуру вне основного ареала. Популяции и внутрипопуляционные группы различаются особенностями морфогенеза листьев. Листья простого строения свойственны популяциям восточной части ареала. В западном направлении происходит уменьшение размеров листьев и усложнение их строения [14].

Цель работы - анализ фенотипической изменчивости Q. robur в 12-ти районах произрастания сухостепной зоны Украины в Донецкой области и определение степени их дифференциации. 


\section{Материалы и методы}

Исследования проводились на 12-ти пробных площадях: 4, находящиеся на охраняемых территориях, и 8-ми малочисленных изолированных локальных естественных районов произрастания $Q$. robur (рис. 1). В качестве фенотипических маркеров для оценки изменчивости вида были использованы морфологические признаки листьев (рис. 2), которые характеризуются высокой генотипической обусловленностью и часто используются в популяционных исследованиях $[13,17]$. Образцы листьев в каждой из 12-ти районов произрастания (они же, наши пробные площади) собирали индивидуально, с 30-ти деревьев в каждой локальности. С каждого дерева, для достаточной информативности и репрезентативности выборки, было взято по 10 образцов листьев. Для этого выделяли наиболее типичные растения, характерные из каждой популяции $[13,14,17,23,25-27]$. Измерения признаков производились согласно рекомендациям Л. Ф. Семерикова [13]. Сбор листьев осуществлялся в течение июня 2015 года. Обработка результатов осуществлялись с помощью программ Microsoft Exel и Statistica 10.

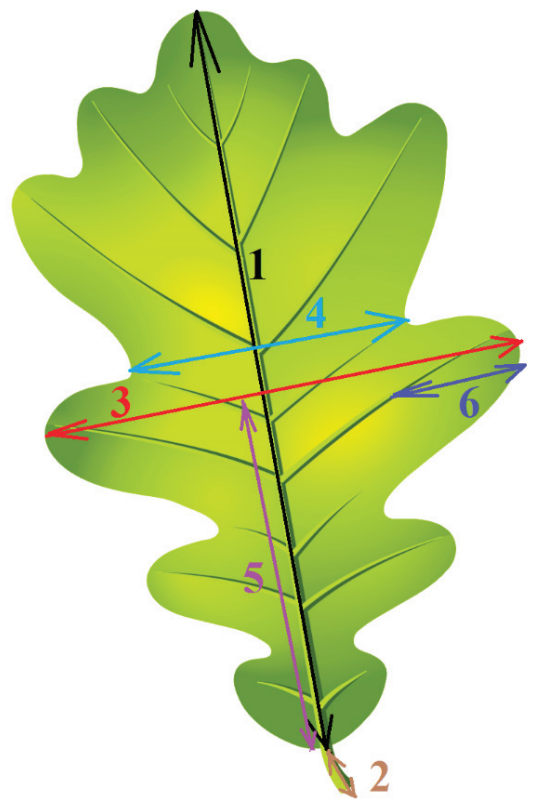

Рис. 2. Основные параметры измерений морфологии листьев дуба в исследовании фенотипической изменчивости

1 - Длина листовой пластинки 2 - Длина черешка

3 - Максимальная ширина листа по лопастям

4 - Максимальная ширина листа по бухтам

5 - Длина от основания до линии наиболее широкого места листа 6- Максимальная высота лопасти

Проанализированы 8 морфологических признаков листьев и включая 3 относительных расчётных показателя трех иерархических уровнях выборки: в пределах каждого дерева (эндогенная изменчивость), в пределах каждой пробной площади (индивидуальная, или внутрипопуляционная изменчивость) и между пробными площадями (эколого-географическая, или межпопуляционная изменчивость) [10]. 


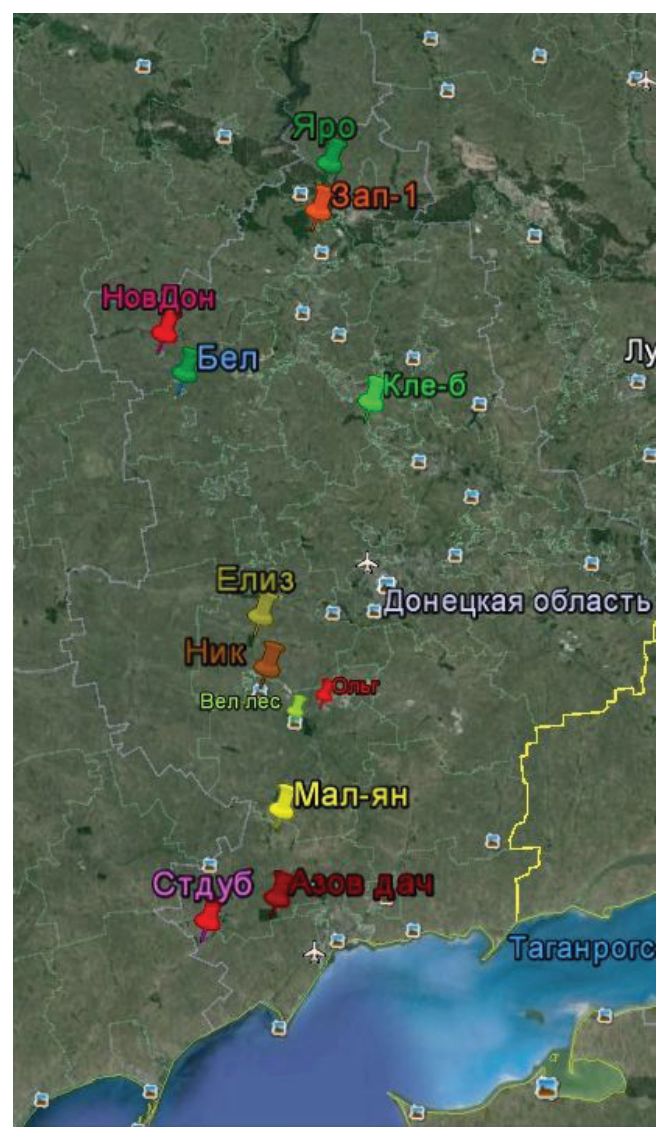

Рис.1. Карта размещения исследуемых местопроизрастаний Q. robur в Донеикой области.

Сокращенные названия районов произрастания, изображенных на интерактивной карте:

$$
\text { 1. ЯРО - Яровая }
$$

2. 3АП-1 - заказник «Заплава-1»*

3. НовДон - Новодонеикое (Добропольский район)

4. БЕЛ-Белозерское (в том числе и вблизи с.Боковое)

5. Кле-б - РЛП «Клебан-бык «* 6. ЕЛИЗ - Елизаветовка 7. НИК - Никольское

8. ВЕЛ ЛЕС - Великоанадольский лес* 9. ОЛЬГ-Ольгинка

10. МАЛ-ЯН - Малоянисоль

11. СТДУБ-Стародубовка (Першотравневый район)

12. АЗОВ ДАЧ - заказник «Азовская дача» *

* - охраняемые территории

\section{Результаты и их обсуждение}

Показатели морфометрических параметров листьев растений Q. robur и их изменчивость в сухостепных условиях произрастания в Донецкой области представлены на таблице 1.

Следует отметить, что средние значения морфометрических данных, полученных нами по степной зоне Украины в Донецкой области, весьма сходны с данными, полученными по схожим характеристикам в регионе Башкирского Предуралья [19].

Полученные данные морфологических показателей листовой пластинки Q. robur следует считать невысокими исходя из исследований дубрав Европейской части РФ и Кавказа Семириковым [13], Среднего Половожья и Чувашии А. С. Яковлева [17], Челябинской области в исследовании Т. М. Гнушевой [1], Западной Европы Ааса [18], Клейншмита, Креймера [22].

Морфометрические данные листьев дуба в Трансильвании (Румыния, Юг Европы) в исследованиях А. Л. Курту оказались ниже наших (длинна листа 


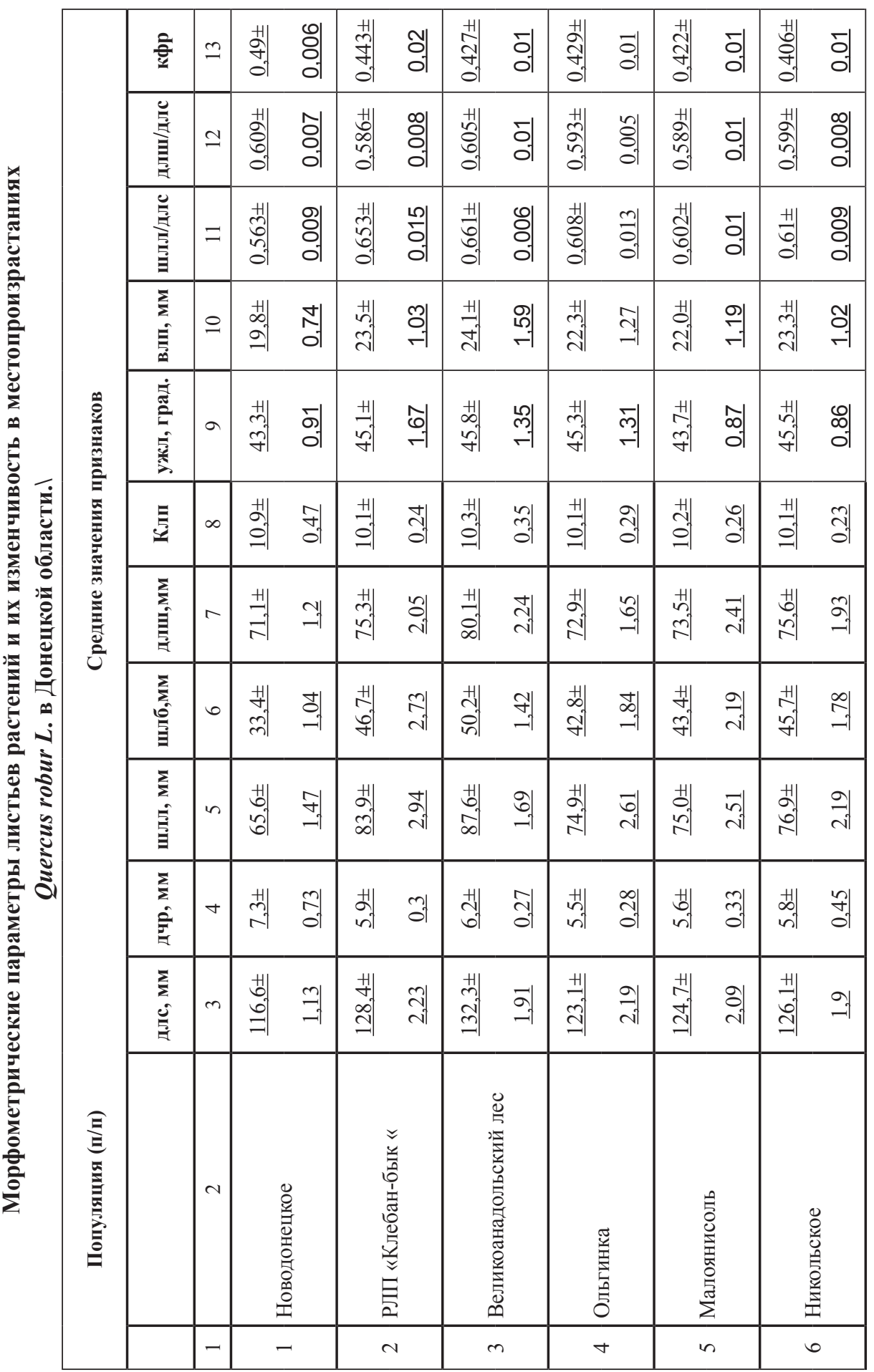


ISSN 2077-1746. Вісник ОНУ. Біологія. 2015. Т. 20, вип. 2(37)

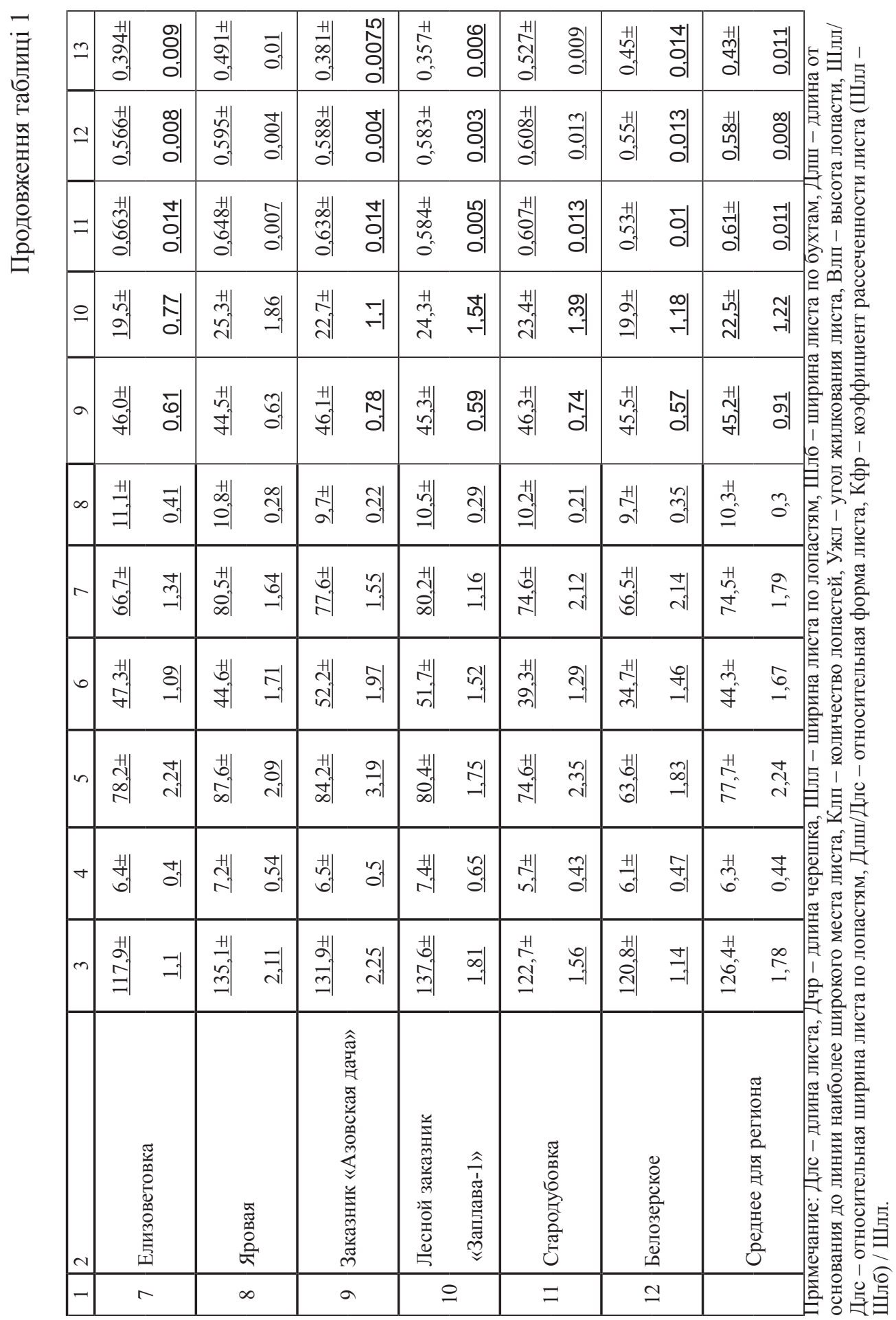


116,91 мм, длина черешка 6,03) [20], что подтверждает тенденцию снижения показателей морфометрии листьев $Q$. robur с западно-центральной части ареала к юго-восточной.

Морфологические признаки сильно различаются по уровню индивидуальной изменчивости (табл. 2). Наиболее вариабельны такие морфологические признаки листьев как: длина черешка, максимальная ширина листа по лопастям, максимальная ширина листьев по бухтам, длина от основания до линии наиболее широкого места листа. Значительно менее изменчивы были: относительная форма листа, относительная ширина листа, количество лопастей, угол жилкования и коэффициент рассеченности листа.

Таблица 2

Значения коэффициентов вариации (CV) параметров листьев в местопроизрастаниях дуба черешчатого Степной зоны Украины

\begin{tabular}{|c|c|c|c|c|c|c|c|c|c|c|c|c|}
\hline $\begin{array}{l}\text { Сокр. } \\
\text { назв. } \\
\text { поп-й }\end{array}$ & 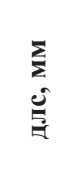 & 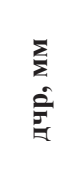 & $\begin{array}{l}\frac{5}{2} \\
5 \\
5 \\
5\end{array}$ & 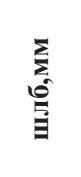 & 言 & 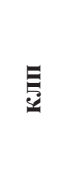 & 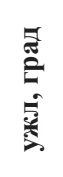 & $\begin{array}{l}\bar{\sum} \\
\bar{E} \\
\bar{E}\end{array}$ & $\begin{array}{l}\frac{\mathscr{E}}{5} \\
\frac{5}{5}\end{array}$ & 旨 & ⿳亠ेषे & $\begin{array}{c}\text { CV1 } \\
\text { сред- } \\
\text { няя по } \\
\text { попля- } \\
\text { ции }\end{array}$ \\
\hline овд & 5,5 & 15,1 & 6,5 & 7,4 & 6,3 & 4,4 & 2,1 & 5,9 & 1,4 & 1,1 & 1,3 & 5,17 \\
\hline ЛП & 6,2 & 10,0 & 7,8 & 10,1 & 7,4 & 2,4 & 3,7 & 6,5 & 2,3 & 1,4 & 4,6 & 5,68 \\
\hline еллес & 5,9 & 9,4 & 6,2 & 7,2 & 7,5 & 3,5 & 2,9 & 8,7 & 0,9 & 1,7 & 2,2 & 5,11 \\
\hline Ольг & 6,3 & 10,1 & 7,7 & 8,6 & 6,9 & 2,9 & 2,9 & 7,9 & 2,1 & 0,8 & 2,6 & 5,35 \\
\hline Іал-л & 6 , & 10,8 & 7,6 &, 4 & 7,9 & 2,5 & 1,9 & 7,6 & 1,8 & $\Omega$ & 3,1 & 5,51 \\
\hline Ник & 6,0 & 12,6 & 7,1 & 8,2 & 7,2 & 2,3 & 1,9 & 6,5 & 1,5 & 1,3 & 2,5 & 5,21 \\
\hline лиз & 5,4 & 11,3 & 7,1 & 6,6 & 6,7 & 3,7 & 1,3 & 6, & 2 , & 1,3 & 2,4 & 4,92 \\
\hline Яро & 6,1 & 12,4 & 6,6 & 8,2 & 6,7 & 2,7 & 1,4 & 9,5 & 1,2 & 0,7 & 2,2 & 5,25 \\
\hline зов да & 6 , & 12 , & 8,0 & 8,1 & 6,7 & 2,3 & 1,7 & 6 , & 2,2 & 0,6 & 1,9 &, 22 \\
\hline Зап-1 & 5,8 & 13,8 & 6,4 & 7,3 & 6,1 & 2,8 & 1,3 & 8,5 & 0,9 & 0,5 & 1,7 & 5,01 \\
\hline Стдуб & 5,8 & 12 & 7, & , & 7,5 & 2,0 & 1,6 & 8, & 2 , & 2,19 & 1,7 & 5,35 \\
\hline Белоз & 5 & 12 & 7, & 8,5 & 7,9 & 3,6 & 1,3 & 8 & 2, & 2,3 & 3,1 & 5,65 \\
\hline $\begin{array}{l}\text { Сред. } \\
\text { CV1 по } \\
\text { признаку }\end{array}$ & 5,9 & 11,9 & 7,13 & 8,1 & 7,1 & 2,9 & 2,0 & 7,5 & 1,7 & 1,3 & 2,5 & 5,28 \\
\hline V2 & 15,8 & 6,51 & 18,5 & 17,9 & 15,4 & 3,9 & 6,4 & 31,9 & 7,2 & 3,2 & 11,2 & 5,30 \\
\hline
\end{tabular}

Прим. CV1 - коэффициент вариации для индивидуальной изменчивости в популяциях, CV 2 коэффициент вариации для межпопуляционной изменчивости в регионе. 
Сравнение местопроизрастаний (локальностей, популяций) по уровню варьирования каждого признака в отдельности малоинформативно [10, 13]. В качестве общей меры внутрипопуляционной (индивидуальной) изменчивости был использован обобщенный коэффициент вариации, рассчитываемый посредством усреднения коэффициентов вариации разных признаков или средние значения по популяции CV1.

Как видно, исследованные местопроизрастания $Q$. robur довольно близки друг к другу по уровню внутрипопуляционной (индивидуальной) изменчивости (табл. 2). Показатель индивидуальной изменчивости по исследованным 12 -ти районам произрастания в среднем составил 5,3\%.

Согласно общепринятой шкале С. А. Мамаева [7] степень изменчивости изученных морфологических признаков листьев дуба оценивается как невысокая. Вероятнее всего, это обусловлено тем, что, несмотря на обширное количество исследованных районов произрастаний, географический охват территории был небольшим (расстояния между самыми крайними местопроизрастаниями составляет около 300 км). Показатели внутривидовой изменчивости Q. robur в Европейской части РФ и Западной Европы были выше [1, 11, 13, $14,18,20,22]$.

Анализ иерархической кластеризации (на эколого-географическую изменчивость) 12 -ти районов произрастания дуба черешчатого ( $Q$. robur $L$. ) в Донецкой области показывает 2 четко разграничивающихся кластера (рис. 3 ).

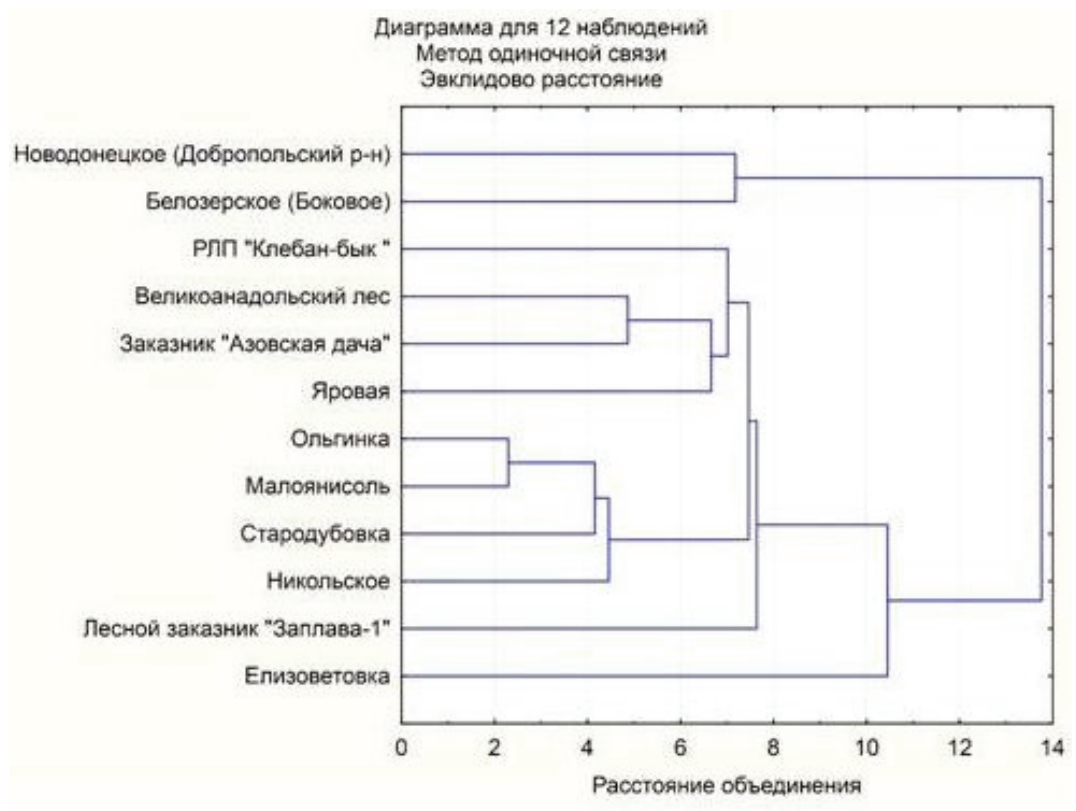

Pис.3. Дендрограмма различия-сходства пробных площадей Quercus robur L. по морфологическим признакам листьев растений Степной зоны Украины 
Сопоставление построенной дендрограммы с географическим положением древостоев свидетельствует, что пробные площади Новодонецкое и Белозерское очень сильно обособлены от всех остальных. Эти 2 локальности произрастания дуба расположены недалеко друг от друга (около 15 км), но сравнительно далеко от остальных. Возможно, это можно объяснить специфичностью маршрутов распространения пыльцы, что можно определить посредством проведения молекулярно-генетических анализов.

Из второй общей группы, где представлены остальные 10 районов произрастания, можно выделить 3 подгруппы (подкластера). В первую подгруппу вошли 4 исследуемых участка: РЛП «Клебан-бык», Великоанадольский лес, Заказник «Азовская дача» и Яровая. Эти популяции, скорее, объединены не случайно, так как все эти 4 популяции находятся на охраняемой территории.

В следующую подгруппу второго кластера вошли еще 4 района произрастания: Ольгинка, Малоянисоль, Стародубовка и Никольское. В этих древостоях отсутствует природоохранный режим или статус, в отличие от предшествующей подгруппы. И в последнюю подгруппу второго кластера, весьма условно, вошли популяции Заплава-1 и Елизаветовка. При этом, данные этих популяций и их географическое расположение не имеют существенного сходства между собой. Скорее, эти популяции попали в отдельный сегмент исключительно изза данных анализа, которые отличались весьма маргинальными показателями и имели слабое сродство с остальными.

Наибольшая зона распределения (зона из 10-ти популяций) по значениям морфометрии листьев дуба свидетельствует о формовом разнообразии дуба на южной границе его ареала.

Вероятно, два резко различающихся кластера могут свидетельствовать о том, что это две популяции дуба черешчатого. Для подтверждения данной гипотезы необходим тщательный молекулярно-генетический анализ.

Таким образом, относительные значения величины и формы листьев $Q$. robur могут служить информативными признаками для установления внутривидового таксономического ранга его популяций и их географических и экологических компонентов.

\section{Выводы}

1. Анализ 12-ти местопроизрастаний дуба черешчатого Q. robur в Степной зоне Украины по морфометрическим признакам листьев показал широкий диапазон вариабельности по каждому признаку и, соответственно, высокую эндогенную изменчивость. Полученные результаты сопоставимы с таковыми по другим участкам ареала распространения вида.

2. Исследованные пробные площадки показали невысокий уровень индивидуальной (внутривидовой) изменчивости, согласно общепринятой шкале изменчивости Мамаева, по исследуемому региону $-5,3$ \%. 
3. Результаты исследований эколого-географической (межпопуляционной) изменчивости районов произрастания с помощью иерархической кластеризации предварительно свидетельствуют о дифференциации дуба черешчатого в районе исследований на две неравноценных группы. Возможно, эти две группы являются отдельными популяциями, для подтверждения чего необходимо проведение молекулярно-генетического анализа. Также отметим, что местопроизрастания дуба, которые охватывают второй кластер (10 популяций), те, которые расположены севернее, они имеют гораздо более высокие значения показателей морфометрии листьев растений, чем южные. Если брать во внимание результаты анализов и географическое положение популяций, то, во многих случаях, можно найти закономерное следствие.

4. Сохранение генофонда дуба черешчатого (Q.robur) в регионе следует вести с учетом популяционной дифференциации вида и выделение популяций с наибольшим уровнем фенотипической изменчивости, таких как Яровая, Заплава-1, Великоанадольский лес.

\section{Список использованной литературы}

1. Гнушева Т. М. Внутривидовая дифференциация дуба черешчатого на внутрипопуляционные группы, географические и экологические ценопопуляции в разных частях ареала / Т. М. Гнушева, А. П. Кожевников, М. В. Крутов // Научные ведомости БелГУ Серия Естественные науки. - 2012. - № 9 (128). Выпуск 19. - C. $5-8$.

2. Данъшин И. И. Долговечность насаждений дуба в зависимости от физико-механических свойств южных чернозёмов Ростовской области / И. И. Данъшин, А. А. Василькович // Лесоразведение на Среднем Дону. - Воронеж, 1973. - С. 81-91.

3. Ерусалимский В. И. Лесоразведение в степи текст / В. И. Ерусалимский. -М.: ВНИИЛМ, 2004. 176 с

4. Карпеченко K. A. Изучение метаболизма плюсовых деревьев дуба черешчатого (Quercus robur L.) / К. А. Карпеченко, И. Ю. Карпеченко, О. А. Землянухина, В. Н. Вепринцев, А. М. Кондратьева, Н. А. Карпеченко, В. Н. Калаев // Фундаментальные исследования. - Воронеж, 2013. - № 1. - С. 287-291.

5. Ковалевич А. И. Рекомендации по генетической инвентаризации объектов лесосеменной базы и их использованию: утв. М-вом лесного хозяйства Респ. Беларусь 06.03.12 / А. И. Ковалевич. - Минск, 2012. $50 \mathrm{c}$

6. Лосиикий К. Б. Дуб. / К. Б. Лосицкий. - М.: Лесная промышленность, 1981. - 101 с.

7. Мамаев С. А. Формы внутривидовой изменчивости древесных растений / С. А. Мамаев. - М.: Наука, 1973. $-284 \mathrm{c}$.

8. Арефьев В. А. Молекулярная биология и генетика. Толковый словарь, «Англо-русский толковый словарь генетических терминов» [Электронный ресурс] // Москва: Изд-во ВНИРО, 1995 г. - режим доступа: http://dic.academic.ru/dic.nsf/genetics/7932

9. Мениикий Ю. Л. Обзор видов рода Quercus L. Евразии / Ю. Л. Меницкий. - Л.: Наука, 1982. - 60 с.

10. Путенихин В. П. Лиственница Сукачева на Южном Урале (изменчивость, популяционная структура и сохранение генофонда) / В. П. Путенихин. - Уфа: УНЦ РАН, 1993. - 195 с.

11. Путенихин В. П. Фенотипическая структура дуба черешчатого в Башкирском Предуралье как основа сохранения генофонда вида в регионе / В. П. Путенихин // Известия Самарского научного центра Российской академии наук. 2013. - Т. 15, № 3 (4), Самара, 2013. - С. 1410-1412.

12. Родин С. А. Теоретические и практические аспекты повышения результативности искусственного выращивания леса / С. А. Родин, А. Р. Родин // Лесное хозяйство - 2005, № 1. - С. 36-39.

13. Семериков Л. Ф. Популяционная структура дуба черешчатого (Quercus robur L.) в Поволжье и Предуралье / Л. Ф. Семериков, В. С. Казанцев // Экология. - 1979. - № 2. - С. 12-21.

14. Семериков Л. Ф. Популяционная структура древесных растений (на примере видов дуба Европейской части СССР и Кавказа) / Л. Ф. Семериков. - М.: Наука, 1986. - 140 с. 
15. Усецкий И. М. Проблема усыхания дубрав Украины Текст. / И. М. Усецкий, В. Л. Мешкова // Дуб. - порода третьего тысячелетия: Сборник научных трудов Института леса Национальной АН Беларуси. Вып. 48. Гомель, 1998. - С. 313-318.

16. Харченко H. А. К вопросу о естественном возобновлении дуба черешчатого под пологим материнским древостоем / Н. А. Харченко, Н. Н. Харченко // Науч. журн. КубГАУ. - 2012. - № 76. - С. 1-13.

17. Яковлев А. С. Дубравы Среднего Поволжья / А. С. Яковлев, И. А. Яковлев. - Йошкар-Ола: МарГТУ, 1999. $-352 \mathrm{c}$

18. Aas G. Taxonomical impact of morphological variation in Quercus robur and Q. petraea: a contribution to the hybrid controversy/ Aas G. // Ann. Sci. For. 50 (1993) - P. 107-114.

19. Buschbom J. Efficient Long-Distance Gene Flow into an Isolated Relict Oak Stand / J. Buschbom, Y. Yanbaev, B. Degen // Journal of Heredity. - 2011. - 102, № 4. - P. 464-472.

20. Curtu Alexandru. Leaf morphological and genetic differentiation between Quercus robur L. and its closest relative, the drought-tolerant Quercus pedunculiflora K. Koch. / Alexandru Curtu, Sofletea, Alin Toader, Mihai Enescu // Annals of Forest Science, Springer Verlag (Germany) - 2011, 68 (7) - P. 1163-1172.

21. Kelly P. M. Climate and signature years in west European oaks / P. M. Kelly, M. A. R. Munro, M. K. Hughes, C. M. Goodness // Nature. - 1989. - 340 (6228). - P. 57-60.

22. Kleinschmit J. R. G. Comparison of morphological traits of pedunculate oak (Q. robur L.) and sessile oak $(Q$. petraea Matt.) Liebl. / J. R. G. Kleinschmit, R. Bacilieri, A. Kremer, A. Roloff // Silvae Genet. - 1995. - 44. P. 256-269.

23. Heredia Lo pez de. Variation components in leaf morphology of recruits of two hybridising oaks $[Q$. petraea (Matt.) Liebl. and Q. pyrenaica Willd.] at small spatial scale/ Lo `pez de Heredia, U. et al. // Eur. J. For. -2009. Res. 128. - P. 543-554.

24. Petit R. J. Chloroplast DNA variation in European white oaks / R. J. Petit, U. M. Csaikl, S. Bordács // Forest Ecology and Management. - 2002. - 156, № 1-3. - P. 5-26.

25. Viscosi $V$. Geometric morphometric analyses of leaf variation in four oak species of subgenus Quercus (Fagaceae) / V. Viscosi // Plant Biosyst. - 2009a. -143. - P. 575-587.

26. Viscosi $V$. Leaf morphological analyses in four European oak species (Quercus) and their hybrids: a comparison of traditional and geometric morphometric method/ V. Viscosi // Plant Biosyst. - 2009b. - 143 - P. 564-574.

27. Viscosi $V$. Geometric morphometric analysis as a tool to explore covariation between shape and other quantitative leaf traits in European white oaks / V. Viscosi // Tools for identifying biodiversity: progress and problems. Univ. Press. 2010. - Vol. 1. - P. 257-261.

28. Yan Z. Trends of extreme temperatures in Europe and China based on daily observations/ Z. Yan, P. D. Jones, T. D. Davies et al. // Climatic Change. - 2002. - 53. - P. 355-392.

\section{О. О. Слєпих, І. І. Коршиков}

Статья поступила в редакцию 04.09.2015

${ }^{1}$ Криворізький ботанічний сад НАН України

вул. Маршака, 50, Кривий Ріг, 50089, Україна, e-mail: aleksandr_slepykh@mail.ru

\section{МIНЛИВIСТЬ ДУБА ЧЕРЕШЧАТОГО (QUERCUS ROBUR L.) ЗА ФЕНОТИПІЧНИМИ ОЗНАКАМИ ЛИСТЯ У СТЕПОВІЙ ЗОНІ УКРАЇНИ РЕЗЮМЕ}

Досліджено мінливість (ендогенну, індивідуальну та еколого-географічну) 12 ти місцезростань дуба черешчатого $(Q$. robur $L$.) в умовах сухостепової зони на Донбасі за морфологічними ознаками листя. Виявлено високу варіабельність 8 емпіричних і 3-х відносних показників. Рівень індивідуальної мінливості дібров Українського степу склав 5,3 \%. На основі показників морфометрії листя був проведений кластерний аналіз, який виявив дві нерівноцінні групи, в одну з яких увійшло 10 досліджуваних районів зростання.

Ключові слова: Quercus robur L., морфологічні ознаки, фенотипічна мінливість, популяція, кластерний аналіз. 


\begin{abstract}
A. A. Slepykh, I. I. Korshikov
Krivoy Rog Botanical Garden under NAS of Ukraine

50, Marshak st., Krivoy Rog, 50089, Ukraine, e-mail: aleksandr_slepykh@mail.ru

VARIABILITY OF ENGLISH OAK (QUERCUS ROBUR L.) ON THE BASIS OF PHENOTYPIC TRAITS OF LEAVES IN THE STEPPE OF UKRAINE
\end{abstract}

\begin{abstract}
We have investigated phenotypic variability (endogenous, intraspecific or individual, ecological and geographical or interpopulation) 12 of stand English oak (Q. robur L.) in the zone of an arid steppe in eastern Ukraine using morphological characters of leaves. We have identified high variability of 8 empirical and 3 relative traits of leaves. The level of individual variability of oak of the Ukrainian steppe amounted to $5,3 \%$. On the basis of morphometric parameters of leaves, a cluster analysis was performed, which revealed two unequal groups, one of which included 10 investigated habitat of English oak, into the other - 2. A hypothesis is proposed that these two groups originated from two distinct populations through genetic drift and migration of genes. Conservation of the gene pool of English oak (Q. robur) in the Ukrainian steppe will be carried to the type of population differentiation and allocating populations with the highest level of phenotypic and genotypic variability. Keywords: Quercus robur L., morphological traits, phenotypic variability, population, cluster analysis.
\end{abstract}

